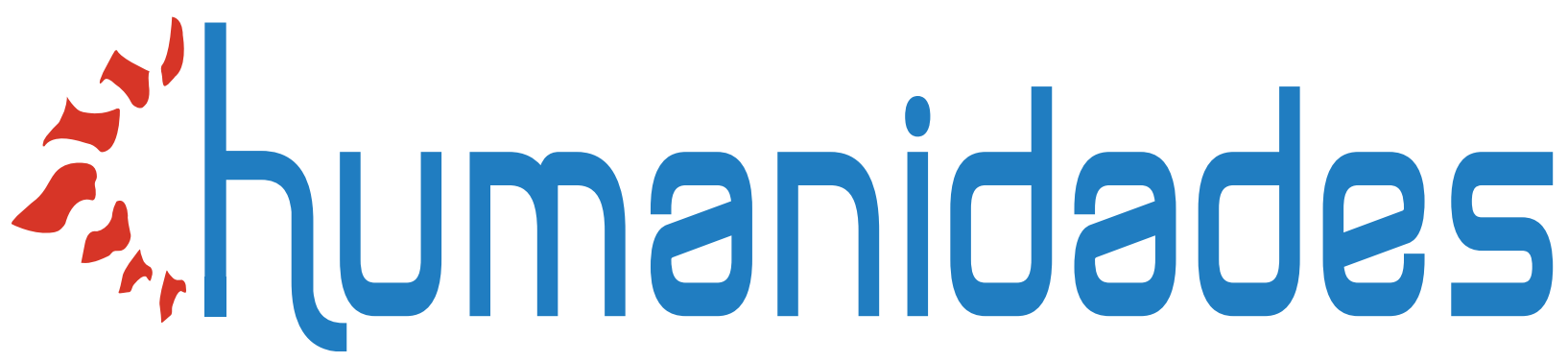

\title{
Azerbaijan Democratic Party: Ups and Downs (1945-1946)
}

Mohammad Soleimani Amiri

DOl: https://doi.org/l0.155 I7/h.v I0il .39936 https://revistas.ucr.ac.cr/index.php/humanidades/index 


\section{thumanidades}

Revista Humanidades

ISSN: 2215-3934

humanidades@ucr.ac.cr

Universidad de Costa Rica

Costa Rica

\section{Azerbaijan Democratic Party: Ups and Downs (1945-1946)}

Soleimani Amiri, PhD. Mohammad

Azerbaijan Democratic Party: Ups and Downs (1945-1946)

Revista Humanidades, vol. 10, núm. 1, 2020

Universidad de Costa Rica, Costa Rica

Disponible en: http://www.redalyc.org/articulo. oa?id=498060395015

DOI: https://doi.org/10.15517/h.v10i1.39936

Todos los derechos reservados. Universidad de Costa Rica. Esta revista se encuentra licenciada con

Creative Commons. Reconocimiento-NoComercial-SinObraDerivada 3.0 Costa Rica. Correo electrónico:

humanidades@ucr.ac.cr/ Sitio web: http: //revistas.ucr.ac.cr/index.php/humanidades

Esta obra está bajo una Licencia Creative Commons Atribución-NoComercial-SinDerivar 3.0 Internacional. 
Desde las ciencias sociales, la filosofía y la educación

\title{
Azerbaijan Democratic Party: Ups and Downs (1945-1946) \\ Partido Demócrata de Azerbaiyán: altibajos (1945-1946)
}

PhD. Mohammad Soleimani Amiri

University of Sapienza, Italia

DOI: https://doi.org/10.15517/h.v10i1.39936

mohammadsoleymaniamiri@gmail.com

Redalyc: http://www.redalyc.org/articulo.oa?

(iD http://orcid.org/0000-0002-0554-6964

$\mathrm{id}=498060395015$

Recepción: 19 Junio 2019

Aprobación: 23 Noviembre 2019

\begin{abstract}
:
Democratic Party of Azerbaijan's movement is one of the most important events in the history of Iran and the world. It was for the first time in the history of Iran that a political party seriously stressed the issue of autonomy. In addition, this movement as liberation movement prioritized several decisive and fundamental reform. Most important of all, Iran's complaints of the Soviet Union in the Security Council and the confrontation of superpowers led to the Cold War. This study attempts to analyze this issue using several Persian, English, Russian and Turkish resources. The present paper concludes that the emergence of the Democratic Party movement was the result of internal and external in addition, objective and subjective factors.
\end{abstract}

KeYwords: Democratic Party of Azerbaijan, Northern Oil Concession, Security Council, Red Army, Cold War.

\section{RESUMEN:}

El movimiento del Partido Demócrata de Azerbaiyán es uno de los eventos más importantes en la historia de Irán y el mundo. Fue por primera vez en la historia de Irán que un partido político enfatizó seriamente el tema de la autonomía. Además, este movimiento como movimiento de liberación priorizó varias reformas decisivas y fundamentales. Lo más importante de todo, las quejas de Irán de la Unión Soviética en el Consejo de Seguridad y la confrontación de las superpotencias llevaron a la Guerra Fría. Este estudio intenta analizar este problema utilizando varios recursos persas, ingleses, rusos y turcos. El presente artículo concluye que la aparición del movimiento del Partido Demócrata fue el resultado de factores internos y externos, además de factores objetivos y subjetivos.

Palabras clave: Partido Demócrata de Azerbaiyán, Concesión petrolera del norte, Consejo de Seguridad, Ejército Rojo, Guerra Fría.

\section{INTRODUCTION}

In 1945, the Democratic Party of Azerbaijan emerged as a local political party in Azerbaijan. This party called for a kind of local autonomy and had the support of the Soviet Union. The reason for the support of the Soviet Union was to make a pressure to earn the Northern Oil Concession. However, the main purpose of the Russians from obtaining the Northern Oil Concession was to penetrate in the Northern parts of Iran and the Iranian Azerbaijan to prevent the development of the Iranian soil to an imperialist base against the Soviet Union since the leadership of Iran constituted reactionary, rightist, imperialist, antiSoviet and anti-Communist elites. From Soviet leaders' perspective, although Reza Shah was ousted and exiled (September, 1941), the class composition of the Iranian politicians still constituted the conservative landowner aristocracy and nobility as well as the prime ministers and ministers. In addition, since the early 40s, the pro-USA elite came to power in Iran especially that the Iranian government hired American advisors to rebuild the army, the gendarmerie and the police and to improve its economic and financial situation. Thereafter, the influence of the USA in Iran extremely increased. In addition, the representatives of the Iranian and British oil companies came to Iran and engaged in secret negotiations with the Iranian government to obtain the oil concession of the Southern, Southeastern and Eastern areas of Iran. When it was 
revealed, the public views and some of the liberal and pro-Soviet parliament representatives protested against it. In response to these negotiations, the Soviet Union sent its representative Sergey Kavtaradze to obtain the Northern Oil Concession, but the Iranian government was not willing to talk about it and Iran's parliament approved a plan to ban the assignment of any oil concessions to foreign companies and governments. This action of the Iranian Parliament with respect to the previous government negotiations with the Western companies was considered to be unfriendly by the Soviet leaders and cause them to be concerned about the security of their shared borders with Iran. This issue as well as the internal factors such as the Azerbaijanis' familiarity with the socialist ideas due to the shared border with the Soviet Union, the national oppression during Reza Shah's monarchy, poverty, the Tudeh party and trade union freedom due to the presence of the Soviet Red Army in the country and finally, the peasants' fight against the landowners and feudalists, provided the groundwork for the rise of the Democratic Party of Azerbaijan.

In this regard, valuable works have been written by Iranian, Azerbaijani, Russian and American writers. Professor Mikhail Sergovich Ivanov (1966) investigated this issue from the perspective of Sovietism. Ervand Abrahamian, a leading American Iranist dealt with the issue of the role of the internal and external forces in the crisis in his book Iran between Two Revolutions. Jamil Hasanli (2004) examined the documents in the archives of the Soviet Union in this regard. Anvar Khamee and Babak Amir Khosravi (1996), the former members of the Tudeh Party of Iran along with Nosratollah Jahanshahlu, one of the Democratic Party leaders in their memoirs, consider the Azerbaijani Democratic Party as a puppet of the Soviet foreign policy. Touraj Atabaki, the professor of Leiden University in Netherlands, after examining the documents and archives of the Ministry of Foreign Affairs and Ministry of defense of the USA, wrote in his book Azerbaijan in Contemporary Iran that Truman's claim based on sending an ultimatum to Stalin which threat him to use atomic bomb against the Soviet Union is a myth. In this study, the author attempts to comprehensively address the internal and external as well as the objective and subjective causes of the appearance of the Democratic Party of Azerbaijan. The author tries study the nature of the Democratic Party of Azerbaijan. He has also tried to investigate the collapse of the Democratic Party of Azerbaijan from a new and modern perspective.

The aim of this study is to investigate and analyze the causes of the emergence of the party and its suppression from a new perspective and to provide a comprehensive review using several authentic books and documents. To root the events of Azerbaijan in the 40s that led to the Cold War between the two superpowers, the United States of America (USA) and the Soviet Union, the political and economic situation of the region in the nineteenth century and early twentieth century must be studied.

\section{Azerbaijan in the Second Half of the Nineteenth Century}

After the defeat of Iran by the European powers (Russia and Iran wars 1804-1813 and 1825-1828; and war with the Great Britain 1856-1857), Iran lost a large part of its territory in the South Caucasus, Central Asia and Afghanistan. In addition, the European governments imposed the free trade treaties on Iran and could obtain numerous advantages in the political and economic fields in Iran. The influx of foreign goods and capital led to the bankruptcy of the national bourgeoisie, lockouts and unemployment of domestic workers. Moreover, the landowners and feudalists' oppression made life very difficult for the Iranian peasants. Since the second half of the nineteenth century that the oil resources in Caucasus and Baku were discovered, many unemployed Iranian workers and peasants emigrated to the Central Asia, Caucasus and Russia to find a job. In there, they got familiar with the socialist and radical thoughts and communicated with the Russian socialist revolutionaries. The reason for this was the very hard working conditions and also the tyranny and oppression in Tsarist Russia.

Eric Fromm believes that seasonal workers who travel from region to region transfer the thoughts of the area where they work on their own hometown (Holiday, 1979, p. 135). Since the Iranian and Azerbaijani 
workers and peasants returned to their country, they transferred radical leftist opinions to the northern provinces of Gilan and Azerbaijan.

In 1905, the Constitutional Revolution in Russia triumphed. A year before that, the Iranian intellectuals living in Caucasus established the Social Democratic Party and its subsidiaries secretly in Iran and particularly, in Gilan, Tehran, and Iranian Azerbaijan. It should be noted in the following that Russia had a prominent impact on the Constitutional Revolution of Iran, because Qajar court explicitly asserted that it was a protectorate of Russia and both regimes had very warm and friendly relations due to similarities in their political system. Thus, the weakening of the Russian government practically caused the weakening of Qajar autarchy. On the other hand, because of the changes that had taken place in the nineteenth century, the businessmen, as well as intellectual students and Qajar princes traveled to Europe. This caused the Iranians to get familiar with the modern ideas such as liberalism, market economy, rule of law, parliament, free press, constitution, etc., a combination of subjective and objective factors caused the Constitutional Revolution in Iran to win in 1906. However, only less than two years after the revolution, the new Shah of Iran bombarded the parliament with the encouragement of the Tsarist Russia and arrested, deported, tortured or executed the pro-democracy activists.

\section{Azerbaijan Resistance}

After the coup of Mohammad Ali Shah against the Constitution, the people of Azerbaijan led by liberals and intellectuals such as Sattar Khan, Baqer Khan, Haydar Amu Oghli, Karbala'i Ali monsieur, Shaikh Salim and seqat-al-Islam revolted against the Shah. Despite the ten-month siege of the city of Tabriz (the capital of Iranian Azerbaijan) that led to famine, the people did not stop fighting until the Russian troops under the pretext of delivering food and aid to the Russian, British and European citizens entered Azerbaijan and occupied Tabriz. However, the Gilani revolutionaries and the Iranian Central states tribes could conquer Tehran, remove Mohammad Ali Shah and re-establish the constitutional system.

\section{Atabak Park Accident and Disarmament of the Revolutionary Armed Azerbaijan}

With the success of the Constitutional Revolution, the Russians and the British brought great pressure on the Iranian government to disarm Sattar Khan and Bagher Khan. For this reason, the Central Government decided to invite Sattar Khan and Bagher Khan and Azerbaijani armed forces on the pretext of celebrating the resistance of the people of Azerbaijan to Tehran. These people gathered in Atabak Park of Tehran, but the Central Government gave an ultimatum to them to surrender their weapons within a few days to the Central Government. When Sattar Khan and Bagher Khan refused it, the government forces surrounded them and the Azerbaijani forces were disarmed after the war.

\section{Russia Ultimatum and Azerbaijan Occupation}

After the revolutionaries' victory over Mohammad Ali Shah, the constitutionalists tried to hire European experts and advisors to organize the economic, financial and judicial conditions in Iran. This act jeopardized the interests of the Great Britain and Russia. Especially when Morgan William Schuster, an American adviser in economic affairs, tried to put an end to the influence of Russia on Iran's economic and financial system by confiscating the property of the former King's brother who owed to the Russian bank. This prompted the Russian government to give an ultimatum to expel Schuster. Despite the acceptance of the ultimatum by the government and the dissolution of the parliament, the Russian troops entered Azerbaijan and after defeating the Armed Forces, executed liberalist people like Sheikh Selim, Seqat-al Islam and Karbalayi Ali Monsieur 
and six other ones. Moreover, they started looting through their feudal affiliates and caused insecurity in Azerbaijan. This indicates that the Atabak Park incident and disarmament of the people of Azerbaijan deprived the Revolution from its natural ally and the revolutionary army and opened the way for the Russian invasion. The Russians remained until the Great October Revolution in Iran when Lenin ordered the return of Russian troops from the northern regions and the Iranian Azerbaijan with the onset of the revolution.

\section{The Revolt of Sheykh Mohammad Khiyabani (Democratic Party of Azerbaijan, IrAN, 1920)}

In 1919, the Great Britain and the Anglophile government of Iran signed a treaty whereby the Iranian government pledged to hire advisors from the Great Britain in all economic, financial and military affairs and the Great Britain pledged to help Iran in the construction of railway give a two-million-Pounds sterling loan to the Iranian government. This treaty made Iran actually a protégé of the Empire of the Great Britain. In Azerbaijan, Sheikh Mohammed Khiabani, a revolutionary during the Constitution, established the Democratic Party of Azerbaijan in April 1920 and protested against the treaty of 1919. At the same time, the Musavat Party in the Northern territory of Aras which was called Aran protested against the Russian revolutionary government and established an independent government called Azerbaijan Democratic Republic. The aim of the Musavat party of changing the name of Aran to Azerbaijan was to stimulate the nationalist feelings of the people living in the South of Aras (the Iranian Azerbaijan) and encourage them to separation and annexation to the Northern land of Aras. Sheykh Mohammad Khiyabani was strongly opposed to any nationalist and pan-Turkist ideas, changed the name of Azerbaijan to Azadistan, the land of freedom. According to the documents of the British military attaché in Tabriz Major Stock stated that "Khiabani's Movement was a democratic movement against the landowners and the pro-Great Britain Central Government and had no intention of separatism" (Ghani, 2010, p. 124). Khiabani's slogan was democracy for Iran and self-determination for Azerbaijan and the organ of the Azerbaijan Democratic Party was the Modern Newspaper.

The Central Government has dispatched a well-known governor who was a member of the Democratic Party of Iran in an attempt to lure the movement leaders. On the other hand, Sheykh Mohammad Khiyabani did not disarm the government Cossacks during his resurrection. As Ivanov said, he did not believe in the mobilization of the masses and was only dependent on the intellectuals (Ivanov, 1966, p. 38).

Finally, the government forces murdered Sheykh Mohammad Khiabani at a sudden influx and broke the revolt. It seems that excessive confidence in the Central Government and its governor, failure to disarm the Cossacks, lack of decisive reforms in favor of the workers and peasants as land reforms and lack of communication with other anti-imperialist liberation movements in the North as well as the impossibility of unity with the Bolsheviks, and the lack of mobilization of the people, were factors causing the failure of the movement.

\section{Azerbaijan under Reza Shah}

The Constitutional Revolution failed to achieve its goals such as democracy, rule of law, economic recovery and independence. Instead, chaos, banditry, insecurity in the cities, famine, the incidence of infectious diseases such as plague, cholera, typhoid, etc., as well as centrifugal and separatist movements, were so serious that Iran's independence and territorial integrity was threatened. Moreover, the occurrence of the anti-colonial liberation movements as well as the Russian Revolution threatened the interests of the Great Britain. It should be noted that some Iranian intellectuals such as Hassan Taghizadeh, Hussein Kazemzadeh Iranshahr, etc., wrote texts in publications such as Iranshahr and Kaveh and Future based on the necessity of 
a strong Central Government that can establish security throughout the country. They also believed that to achieve independence and territorial integrity and independence of the country, the Persian language must be regarded as the only official language and the languages, dialects, costumes and customs of other nations and nationalities of Iran, like the Turks, Arabs, Baluchis, Turkmens, Mazenis, the Gilaks and Lors must be banned. All people should be Iranian foremost and consider Iran as a united nation (Atabaki, 1997, pp. 65-68; Ghani, 2010, pp. 315-316).

These people supported Reza Shah to implement the modernization projects. Reza Shah's aim was to create a modern, centralized sovereign state. He was a nationalist and strongly believed in the glory of the ancient Persia. Reza Shah can be considered a highly chauvinist person with racist thoughts and ideas. According to some historians, he had a strange hatred of the Azerbaijani people and always sent the most violent and cruel military governors to Azerbaijan (Jami, 2012, p.200; Zibakalam, 2010, p. 82).

During Reza Shah's monarchy, despite the vast constructions across the country in the border provinces where other nationalities lived (Kurdistan, Azerbaijan, Khuzistan, Baluchistan, the Iranian Turkmenistan), there were not major investments and consequently, Azerbaijan faced with poverty, inflation, unemployment and recession return. This is while Azerbaijan was flourished as one of the main trading paths with the Europe, Caucasus and Russia, and Tabriz was considered the second capital of Iran. In addition, the Central Government humiliated the language and customs of the people of Azerbaijan.

For example, when the poor quality wheat donkey was brought from the crown lands for the military stables of Azerbaijan, the horses refused to eat it. When the Azerbaijani military governor objected to it, the exchequer governor said, "I will give it to the donkeys in Tabriz to eat it" (he means Tabriz people are) (Jami, 2012, p. 75). In addition, in the reign of Reza Shah, any training and even use of Turkish language was prohibited.

\section{Azerbaijan after the Reign of Reza Shah}

On August 25, 1941 and after Reza Shah's repeated ignorance of the requests from the Great Britain emphasizing the deportation of the German advisors and experts who were considered Nazi Germany and Gestapo spies, Iran was occupied by two neighboring governments and Reza Shah was forced to resign and leave the country.

At this time, a part of Azerbaijani intellectuals founded the Azerbaijan Association led by Mirza Ali Shabestari. This Association held Turkish theaters and concerts. The organ of this Association was the Newspaper of Azerbaijan that was published both in Turkish and Persian. The Red Army forces also distributed a Turkish-language newspaper called Vatan- Yulanda (in the way of home country) among the people in Tabriz (it was published for the Turkish-speaking soldiers of the Soviet Army).

\section{Competition over Oil Concession}

In 1943, the representatives of the British and American oil companies of Royal Dutch Shell, Standard Oil and Socony Vacuume came to Iran and negotiated secretly to obtain the Oil Concessions of the Southern, Eastern and Southeastern areas. When these negotiations were disclosed, the public thought, the national bourgeoisie and the Tudeh Party strongly opposed to it. In response to these developments, the Soviet Union sent the vice president of People's Commissars, Sergey Kavtaradze to Iran to obtain the Northern Oil Concession. Despite the favorable conditions of the Soviet Oil Concession, the Iranian government and parliament consisting of the conservative aristocracy dependent on the national bourgeoisie and West liberals strongly opposed to it. The Tudeh Party set a protest in support of the Oil Concessions in Tehran and other cities of Iran. Similarly, in Azerbaijan, about seventy thousand people protested in favor of the 
Oil Concession. The reason was that after the war, the Red Army orders to the local factories would have ended thus the factories would be shut down and the workers would be unemployed (Azimii, 2008, p. 208; Fawcett, 1995, p. 49). After a while, Kaftaradezeh angrily left Iran.

\section{Democratic Party of Azerbaijan}

\section{External Causes of the Emergence of the Democratic Party of Azerbaijan}

Previously, both the objective and subjective aspects of the internal causes of the emergence of the Azerbaijan movement has been investigated. In this section, the external causes of the Azerbaijan democratic party will be discussed. One of the most important causes was the victories of the Red Army over Hitler fascism claiming racial and national superiority. In addition, the Soviet Union had begun the establishment of popular democracies in the Central and Eastern Europe. At the same time, the process of decolonization began in the colonial and semi-colonial nations and the anti-imperialist liberation movements led to victory in these areas. At the same time, the socialist revolution of Vietnam had triumphed and the revolution of China reached its peak. These issues inspired the people and intellectuals of Azerbaijan in rebellion against the Central Government of Iran that was conservative and dependent on the West.

However, the most important factor has been the demand for obtaining the Northern Oil Concession by the Soviet Union. Some historians believe that the Soviet government used the movement of Azerbaijan as a winning card and lever of pressure on the Iranian government to earn the Oil Concession (Mark, 1975). However, with return of Kaftaradzezeh to Moscow, he and Lavrentiy Beria proposed to Stalin not to take out the Red Army from Azerbaijan before obtaining the Northern Oil Concession.

According to the documents obtained, Stalin issued commands to create a separatist and autonomyseeking regime in the Iranian and the northern regions of Iran. According to these commands, there must be a self-formed Democratic Party doing some of the major reforms such as supplying Tabriz drinking water, land reform, using Turkish language and employing the native people in the police and gendarmerie and other local agencies were (Sadri \& Nikbakht, 2005, pp. 224-223; Hasanli, 2004, pp. 50-52).

However, Stalin issued commands to create autonomy-seeking movements in the Iranian Turkmenistan, Khurasan (a province in the Northeastern Iran), and Gilan and Mazandaran using local agents in the local offices, recognizing the Turkmen language, autonomy, land reform and allocating 50 percent of the tax for reconstructions (Milani, 2013, p. 138). Although the topic of Stalin's order was to create separatist movements, he used the word self-determination in the documents. Moreover, as will be argued later, it does not seem that Stalin had the intention of annexing the Iranian Azerbaijan to the Soviet Union.

\section{Twelve-point Declaration of Azerbaijan Democratic Party}

On September 3, 1945, Seyed Jafar Pishevari, Haj Mirza Ali Shabestari and Dr. Salamolah Javid, the old Iranian communists, issued a twelve-point declaration. The provisions of this declaration included providing autonomy for Azerbaijan, supplying Tabriz drinking water, doing land reforms and supporting agriculture and industries, constructing factories and providing jobs as well as respecting the territorial integrity and national sovereignty of Iran (Alamooti, 1991, pp. 454-466; Atabaki, 1997, pp. 114-115).

The leadership of the Azerbaijan Democratic Party included Marxist-Leninist revolutionaries, radical petty bourgeoisie, national bourgeoisie, bourgeon nationalists and progressive clergy. This group, because of its class origin, was dependent on the Soviet policies and conservative. The movement body included workers, peasants and urban poor and rural masses, led by the radical revolutionary officers of the Tudeh Party who formed the Fadayen-e Khalq forces (people volunteers' army). 
At the time of Reza Shah, the feudal relations were dominant in Azerbaijan. The major landowners and feudalists exploited the peasants with the help of the gendarmerie forces. For this reason, and to avoid repeating the mistakes of Sheykh Mohammad Khiabani in the disarmament of the government forces, they disarmed the gendarmerie, police and military barracks on November 15, 1945. In the same month, whopping meetings with one hundred fifty thousand people were held in Azerbaijan where the demand for establishing a Constituent Association was raised. In these meeting for the Constituent Association elections, for the first time in the history of Iran, women voted as well.

On December 12, 1945, the Constituent Association was established and the establishment of the independent autonomous government of Azerbaijan was announced. In this parliament, Seyyed Jafar Pishevari, the leader of the Democratic Party was responsible to form a cabinet.

\section{Central Government's Response to the Developments in Azerbaijan}

When Kaftaradezeh left the country, the political situation got extremely tense so that Saed, the conservative pro-West Prime Minister was forced to resign and Morteza Qoli Khan Saham al-Saltane Bayat, who was a moderate and liberal politician, was elected as the substituent Prime Minister. Bayat proposed the formation of a Russian-Iranian Oil Company to Molotov, the Soviet Foreign Commissar but Molotov rejected it. The later events proved that this was Molotov's biggest mistake. Following the failure of Bayat in obtaining the approval of the Russians and the increasing pressure of the Tudeh Party, Bayat was forced to resign. Instead, Mohsen Sadr (Sadr Al-Ashraf) came to power that was considered a reactionary person by the national-liberal bourgeoisie and the Tudeh Party because of his acts for suppressing the liberalist mass during the Constitutional period. Sadr tried to send a conservative rightist element that was hated by the Azerbaijani people and the leftist and liberal parties (Mehdi Khan Mu'tassim Alsaltaneh Farokh) as the Governor to Azerbaijan but due to the strong opposition of the Democratic Party, he refused extradition to Azerbaijan. Finally, because of the parliament minority's opposition (Tudeh and Monfaredin Fractions), Sadr Al-Ashraf was forced to resign and Hakimi came to power after him. Hakimi was also like the former Prime Ministers, one of the pro-West conservative landowners. Basically, the Soviet leaders believed that the Iranian politicians were the reactionary rightist, conservative, pro-West and anti-communist aristocracy, nobility, landowners and feudalists with a class composition which had not been changed after the overthrow of Reza Shah Pahlavi. Therefore, if they leave the Iranian territory without obtaining any points or concessions, it is likely that the Iranian government give the country to the imperialism to threat the Soviet Union as Reza Shah converted Iran to the fascists base against the Soviet Union.

However, Hakimi first sent Bayat as the governor to Azerbaijan. During Bayat's negotiations with the Azerbaijan movement's leaders, it turned out that he did not want to negotiate but he sought to buy time to prepare the Central Government to suppress the Democratic Party and that is why the negotiations failed. After the failure of the negotiations, the government of Iran sent the military forces to Azerbaijan to suppress the Democratic Party but these forces were stopped by the Red Army at a distance of one hundred and twenty kilometers far from the South of Tehran. When the Iranian government protested to this act of the Red Army to the Soviet Embassy, the Soviet government announced in response that the entry of the Iranian forces in Azerbaijan causes chaos and bloodshed and the Soviet government is forced to secure its barracks by sending additional forces to Iran despite its reluctance to do so (Zoghi, 1989, p. 250).

After that, the Iranian government representative complained about the Soviet Union in the Security Council of the United Nations. This was the first complaint of a country against another one in the Security Council of UN. In the flow of the complaint of the Iranian government, the governments of the USA and the Great Britain actively supported the Iranian government. 


\section{The Tripartite Commission}

After the Soviet refusal to evacuate Iran, Ernest Bevin, the foreign minister of the Great Britain suggested in the Moscow Conference that a Tripartite Commission composed of the representatives of the governments of the USA, the Soviet Union and the Great Britain must be formed. This Commission proposed to the Iranian government that the state provincial council elections should be under the supervision of the representatives of the allies. It also proposed that the local languages such as Arabic, Turkish, Kurdish, etc., should be allowed to be used by the people. The Commission respected the independence and sovereignty of Iran (Pahlavi, 2006, p. 46; Houshang Mahdavi, 2007, p. 108; Khamaee, 1984, pp. 456-457).

Hakimi secretly accepted Bevin's suggestions on condition that two representatives from Iran be also present when decisions are made and the decisions be appropriate to the Iranian Constitutional Law. When the news was released, the public thought and the national liberal bourgeoisie strongly criticized Hakimi. Dr. Mosadeq even compared the Tripartite Commission with the Treaty of 1907 (between Tsarist Russia and the Great Britain) which was signed to divide Iran to influence area and appreciated the Soviet Union for rejection of this plan. The Soviet Union also rejected it because of its contradictions with Iran independence and national sovereignty. The pressure of the public thought and the parliament representatives finally caused the resignation of Hakimi and the substitution of Qavam.

\section{Qavam's Government and the Withdrawal of the Red Army from Iran}

Following the resignation of Hakimi, Ahmad Qavam came to the power with the support of the liberal national bourgeoisie, the representatives of the Tudeh Party and the governments of the USA and the Soviet Union although the Shah and the court as well as the Great Britain and the Anglophile nobility were opposed to him. Qavam initially arrested some pro-Great Britain elements, and then traveled to Moscow for direct negotiations with the Soviet leaders. In Moscow, the Russians first asked for the coordination of the foreign policies of Iran with the Soviet Union, and then, they demanded for the recognition of the autonomous government of Azerbaijan, and the assignment of the Northern Oil Concession to the Soviet Union by the Central Government of Iran (Houshang Mahdavi, 2007, pp. 425-426).

Following Qavam's rejection, the Russians announced that instead of the assignment of the Northern Oil Concession, they are ready to sign another contract with the purpose of establishing an Iranian-Russian oil corporation to exploit the oil of the Iranian Azerbaijan but Qavam opposed to it referring to the law of December 2, 1944, according to which the assignment of the oil concession was prohibited. In their proposal, the Russians suggested some recommendations including recognition of the autonomous government of Azerbaijan, installing the head of the autonomous government as the governor, allocating $75 \%$ of the taxes for construction of the province, selecting the heads of some of the main offices by the State Council of Azerbaijan, and using the Turkish language. However, the Iranian government opposed to all of them referring to their contradiction to the national sovereignty and the Constitutional Law of Iran. In response, the Russians asked for the Northern Oil Concession for the second time. Therefore, the negotiations failed and it was only accepted that the Soviet Union send a new ambassador to Iran.

\section{Qavam-Sachicov's Contract and the Withdrawal of the Red Army from Iran (April 4, 1946)}

On March 25, 1946, Radio Moscow suddenly announced that all disputes with Iran had been resolved and the forces of the Red Army would leave Iran within 5-6 weeks. At the same time, the oil corporation contract was signed between the Prime Minister of Iran and the Soviet ambassador, Ivan Sadchicov. According to this 
contract, an oil corporation with a share of $51 \%$ for the Soviet Union and $49 \%$ for Iran was formed for 50 years. The Red Army forces evacuated Iran in 1.5 months and the issue of Azerbaijan was also considered a domestic problem that should have been solved by the Central Government of Iran with benevolence (Foran, 1994, p. 409; Hess, 1974).

After the withdrawal of the Red Army, Qavam published a seven-point declaration and invited the Democratic Party representatives to come to Tehran for negotiations. However, the negotiations between Qavam and Pishevari failed because of disagreements over how to appoint the governor and military commanders. On June 13, 1946, Pishevari and Mozafar Firooz as the Deputy Prime Minister and the Central Government Representative signed an agreement with 13 items. According to this treaty, the Democratic Party of Azerbaijan ignored its autonomy and the State Council of Azerbaijan was formed instead of the Autonomous Government of Azerbaijan. The heads of the agricultural and financial departments as well as the other important offices were appointed by the State Council and $75 \%$ of the province tax was spent on the development of Azerbaijan. The Turkish language was used besides the Persian language in schools and offices. The government also announced that it would agree with the main principles of the land reform and the increase of the number of the representatives of Azerbaijan Province provided that the parliament accepts it (Hasanli, 2004, p. 162; Foran, 1994, p. 419).

After signing this agreement, the political environment of the country got extremely radical. The Tudeh Party launched workers' strikes in the Southern Oil Industry and in July 1946, the Tudeh Party, the Democratic Party of Azerbaijan, the Democratic Party of Kurdistan and several other parties announced the formation of the Allied Liberal Front.

\section{Why the Red Army Left Iran?}

Several views have been presented regarding the withdrawal of the Red Army from Iran. The most popular view is that Harry Truman, the USA President sent an ultimatum to Stalin and threatened him that in the case of the remaining of the Red Army in Iran, it would bombard the Soviet Union by the atomic bomb. However, a few other researchers such as Dr. Turaj Atabaki reject this view arguing that there is no document and evidence in the files and archives of the Ministry of Foreign Affairs and the Ministry of Defense of the USA proving that an ultimatum was sent and Truman had bluffed about it. However, some other historians believe that Truman had sent this ultimatum to Stalin orally through General Walter Bedell Smith (Hasanli, 2004, p. 140; Poornazmi-Sisi, 2003, p. 13). It seems that due to the political, economic and diplomatic pressures of the USA and the Great Britain, the necessity of the exit of the Soviet Union from the international isolation, the need to reconstruct the war destructions, the need to help to establish popular democracies in the Central and Eastern Europe as well as the support of the China and Vietnam Revolutions and the liberal anti-colonial movement in Indo-China, the Soviet Union was forced to evacuate Iran. On the other hand, it can be argued that the sudden evacuation of Iran by the Red Army seems to be logically due to the oral ultimatum sent by Truman which threatened the Soviet Union by nuclear weapon.

\section{Qavam's Coalition Cabinet}

In order to buy time and deceive the democratic forces, Qavam announced that he is ready to invite the progressive parties of the country to form a government. Thus, he invited three members of the Tudeh Party and one member of the Iran Party to his cabinet. However, this cabinet lasted only 75 days. This cabinet collapsed due to the anti-communist revolt of the Southern tribes and the resignation of the Cabinet Ministers who were the members of the Tudeh Party. 


\section{Southern Tribes' Revolt}

According to the documents obtained, it seems that the revolt of the Southern tribes was supported by the government of the Great Britain and the Shah and probably Qavam. The Southern tribes led by the landowners and feudalists wanted the dismissal of the Tudeh Party ministers and the obtaining of similar concessions to the Democratic Party of Azerbaijan. After the defeat of the Azerbaijan Democratic Party, Estakhr Newspaper wrote that the Fars tribes' revolt was under the supervision of the Shah and he was totally aware of the plan (Atabaki, 1997, p. 172). Naserkhan Qashqai, a rebellious feudalist stated that the purpose of the Southern Movement was to fight against the Democratic Party and in favor of the independence of the country and the North and South should obey the Central Government (Jami, 2012, pp. 446-447).

\section{Iran Military Attack to Azerbaijan and the Collapse of the Autonomous Government of Azerbaijan}

On December 7, 1946, Qavam (the Prime Minister) announced that in order to properly monitor the elections, the army is dispatched across the whole country including Azerbaijan. Before that, the Democratic Party submitted the city of Zanjan (a city in the Iranian Azerbaijan) to the Central Government which was the door to conquer Azerbaijan. This is the biggest mistake of the Democratic Party because Zanjan was not only in Azerbaijan, but also was the key to conquer it.

The army moved toward Azerbaijan on December 7, 1946, and conquered Tabriz on December 12. In the course of the military operations, hundreds were shot down and 70 thousands of people fled to the Soviet.

There is no specific number about the dead, but the American and British sources reported that this number is between 2500 to 5000 people while the Soviet sources announced that it is about 5000 (Foran, 1994, p. 422). However, Jamil Hasanli, a renowned Azerbaijani author mentioned that this number is 30 000 (Hasanli, 2004, pp. 209-210). One of the monarchist authors believes that 12500 people were killed and missed during the operations of the Democratic Party (Bayani, 1996, p. 648). Mohammad Ali Amoee, a military member of the Tudeh Party cites this number to be about 20000 (Amooee, 1998, p. 25). Some other sources have also mentioned a number of 10000 people (Atabaki, 1997, p. 225).

\section{Democratic Party of Azerbaijan and the Issue of Separation}

One of the accusations of the Shah, the national liberal bourgeoisie and the conservative Iranian and Western historians against the Democratic Party was its desire for separation. However, by referring to the documents, it can be seen that the Azerbaijan Democratic Party, except for a few cases, was always loyal to the independence and territorial integrity of Iran. For example:

Pishevari announced at Tabriz airport that the government should be popular and we will fight until the last breath for freedom of Iran (Sadre Maraghaee, 2002, p. 229).

The Democratic Party slogan was freedom for Iran and autonomy for Azerbaijan. The Party leaders also announced that their aim was to defend the independence and territorial integrity of Iran (Jami, 2012, p. 412).

Ghulam Yahya Daneshian, one of the leaders of the Democratic Party announced that if the libertarians of Tehran invite him, he will go to Tehran with his Azerbaijani troops and free Iran not as a general but as the son of a toiling laborer and peasant (Nikbakht \& Heydari, 2010, pp. 154-155). However, there are cases showing that the Democratic Party was willing to completely separate from Iran; for example, Pishevari wrote in Azerbaijan Newspaper that if the politicians and rascals in Tehran select the reactionary way, Azerbaijan will go alone on its own way. Azerbaijan prefers to be a free Ireland rather than a captive India 
like the rest of Iran (Amirkhosravi, 1996, p. 115). On the other hand, in a very important document that has been released in recent years, Pishevari, Shabestari, Biria and Dr. Javid asked Stalin in a secret letter to help them in the pursuit of full independence from Iran (Hasanli, 2004, pp. 119-120).

However, it seems that these articles were threatening in nature and even the above-mentioned document was due to Pishevari's distrust in the Central Government and particularly Qavam. On the other hand, the events that happened in the future proved that this suspicion was true.

\section{The Soviet Union and Azerbaijan Crisis}

Many Iranian historians and some Western rightist writers accuse the Soviet Union of having the intention of separating the Iranian Azerbaijan from Iran and annexing it to the Soviet Azerbaijan. However, the documents as well as the logic show the opposite. The Soviet Union could obtain the most fertile lands in the Europe as one of its satellites.

On the other hand, the Soviet Union suffered a lot during the war, and the annexation of a dry and poor land such as Azerbaijan had no benefit for it. Kaftaradezeh in a document wrote addressing to Beria that the name of South Azerbaijan should not be used at all because it would have serious consequences for the Soviet Union.

George Kennan, the ambassador of the USA in the Soviet announced that the aim of the Soviet Union from obtaining the Oil Concession is just to earn a guarantee to prevent the conversion of a base against it (Atkin, 2007, p. 69; Hess, 1974).

However, it seems that a fraction of the Communist Party of the Soviet Azerbaijan wanted the disintegration of the Iranian Azerbaijan. According to the obtained documents, Mir Jafar Bagirov presented a plan in which the Iranian Azerbaijan should have joint the Soviet Azerbaijan. In case of non-fulfillment of this plan, the Popular Democratic Republic of Azerbaijan should be formed. In case of failure to execute this plan, a bourgeois-democratic government should be formed in Azerbaijan. And finally, if all these projects failed, the Iranian Azerbaijan should gain considerable autonomy (Roberts, 2011; Raine, 2001).

However, what is certain is that the key decision makers on this issue have been Stalin and Molotov, not Beria nor Baqirov.

\section{Results and Findings}

With the defeat of the movement of Azerbaijan, not only was the issue of national oppression in Iran not resolved, but also it got far more complex. On the other hand, a different kind of hostility and cynicism was created between Iran and the Soviet Union which continued for nearly 15 years.

According to the role of the USA in support of the government of Iran in the Security Council as well as its resistance against the wishes of the Soviet Union, Mohammad Reza Shah was heavily influenced by the USA and dependent on it. This was the beginning of the process of the full dependence of Iran on the government of the USA. On the other hand, the failure of the movement can be considered as a turning point in the onset of the dictatorship of Mohammad Reza Shah since with the withdrawal of the Red Army from the Iranian territory, the influence of the USA and the Great Britain on Iran increased and only two years after December 12, 1946, the Tudeh party was illegalized as the pro-Soviet Communist Party. Four years later, following the coup designed by CIA and the overthrow of the government of the national bourgeoisie (1953), Mohammad Reza Shah established his dictatorship in Iran definitely. But the most important result of this movement was the start of the Cold War and the rivalry between the two superpowers of East and West. 


\section{Conclusion}

According to what has been mentioned earlier, it seems that the emergence of the Democratic Party of Azerbaijan movement was the result of internal and external as well as objective and subjective factors. The internal objective and subjective causes of the emergence of the movement were the leadership of Azerbaijan in the Democratic Movements, common border with the Tsarist Russia and the Soviet and familiarity with the modern radical-socialist thoughts, national oppression and humiliation of local languages, accents and customs, feudalists and gendarmes' tyranny and cruelty toward the peasants, the presence of the Red Army and above all, efforts for obtaining the Northern Oil Concession. The external factors also include the victory of the army over Hitler fascism, the onset of the establishment of the popular democracies in the Eastern and Central Europe with the help of the Soviet Union, the radicalization of the socialist revolutions in China and Vietnam as well as the deepening of the anti-imperialist liberation movements in Indo-china with the active role of the Soviet Union. The Democratic Party of Azerbaijan was composed of a conservative leadership and a revolutionary body and it seems that its lack of the serious resistance against the Central Government army had been this contradiction. The Soviet Union asked for the assignment of the Northern Oil Concession and supported the Movement of Azerbaijan in order to obtain a guarantee from the government of Iran based on its avoidance from making the territory an imperialist base against the Soviet Union. However, it seems that the pressures of the Western countries on the Soviet Union, the support of the Iran's complaint in the Security Council, the need to reconstruct the war destructions, the deceptive maneuvers of the Prime Minister of Iran, and above all, the atomic threat of the Soviet Union caused the withdrawal of the Red Army from the Iranian soil and the failure of the Democratic Party of Azerbaijan.

Qavam's government provided the foundations for the movement failure by deceiving the leaders of the movement of Azerbaijan. According to what has been mentioned so far, it can be concluded that the Democratic Party of Azerbaijan led a Democratic Movement with the intention of democracy for Iran and autonomy for Azerbaijan and despite the claims of the Shah and the Iranian and Western conservative historians, it seems that this movement had no intention of separation.

\section{REFERENCIAS}

Alamooti, Z. (1991). Parts of Iranian social and political campaigns, left movements, chapbakbsh. Tehran, Iran: Chapbakhsh.

Amirkhosravi, B. (1996). The investigation of Tudeh party of Iran from inside (criticism of Kiyanoori's memories, institution of publication and research of didgah. Tehran, Iran: Institution of Publication and Research of Didgah.

Amooee, M. A. (1998). Gem of the time, (the memories), khashe. Tehran, Iran: Khashe.

Atabaki, T. (1997). Azerbaijan in the Iranian contemporary history. M. K. Eshteagh (translator). Tehran, Iran: Toos publication.

Atkin, M. (2007). Neither eastern nor western, the case study about Iranian relations with Soviet Union and United States of America. E. Koulaee, S. D. Aghaee \& E. Mottaghi (translator). Tehran, Iran: Mizan.

Azimi, F. (2008). Crisis democracy in Iran. B. Nozari \& A. Houshang Mahdavi (translators). Tehran: Asim.

Bayani, K. (1996). Azerbaijan Riot according to historical, political and archival documents. Tehran, Iran: Heydari.

Fawcett, L., Egovora, N. \& Robertson, D. (1995). Iran and cold war. K. Bayat (translator). Tehran, Iran: Publication of Foreign Ministry.

Foran, J. (1994). Fragile resistance. A. Tadayyon (translator). Tehran, Iran: Rasa.

Ghani, C. (2010). Iran and rise of Reza Shah: From Qajar dynasty to Pablavi power. H. Kamshad, Niloofar (translator). Tehran, Iran: Niloofar. 
Hasanli, J. (2004). At the down of cold war, the Soviet-American crisis over Iranian Azerbaijan, 1941-1946. M. Hemami (translator). Tehran, Iran: Ney.

Hess, G. R. (1974). The Iranian crisis of 1945-1946 and the cold war. Political science quarterly, 89, 117-146.

Holiday, F. (1979). Iran, dictatorship andpolitical development. M. Yalfani \& A. Tolou (translators). Tehran, Iran: Elm. Houshang Mahdavi, A. (2007). The history of Iranian foreign relationships from Safavid to end of the second world war. Tehran: Amirkabir.

Ivanov, M. S. (1966). Iranian new history. H. Ttizabi \& H. G. Panah (translators). Moscow, Former Soviet Socialist Republics: Tudeh party of Iran publication.

Jami, N. (2012). Past is the leader of the future. Tehran: Negah.

Khamaee, A. (1984). The great opportunity missed, first hand narration from secrets and formation of Tudeh party. Tehran, Iran: Hafteh.

Mark, M. E. (1975). Allied relations in Iran, 1941-1947: The origins of a cold war crisis. Wisconsin magazine of Society, 59, 51-63.

Milani, A. (2013). The Shah, Persian circle. Toronto, Canada: Persian circle.

Nikbakht, R. \& Heydari, A. (2010). Azerbaijan democratic party in Sarab, establishment and activities of democratic party in Sarab city. Tehran, Iran: Museum library and center of documents of Islamic council of Majlis.

Pahlavi, M. R. (2006). Answer to history. H. Abotorabian (translator). Tehran, Iran: Zaryab.

Poornazmi-Sisi, A. (2003). Azerbaijan democratic party (Azerbaijan democrat ferghe si), the one year rule of Pishevari, pajoosshedhaye farhangi. Tehran, Iran: Pajoosshedhaye farhangi.

Roberts, G. (2011). Moscow's cold war on the periphery: Soviet policy in Greece, Iran and Turkey, 1943-1948. Journal of contemporary history, 46, 57-81.

Sadre Maraghaee, A. (2002). From Reza Khan jail to leader of Azerbaijan democratic party: studying of life and ideas of Seyyed Jafar Pishevari and review of rise and fall of Azerbaijan democratic party. Tehran, Iran: Ohadi.

Sadri, M. \& Nikbakht, R. (2005). The stablishment of Azerbaijan democratic party according to unpublished documents. Tehran, Iran: Institution of contemporary history.

Raine, F. (2001). Stalin and the creation of the Azerbaijan democratic party in Iran, 1945. Cold war history, 2, 1-38.

Zibakalam, S. (2010). Iranian social and political development (1941-1943). Tehran, Iran: Samt.

Zoghi, I. (1989). The history of political relationships between Iran and the great powers (1900-1925). Tehran, Iran: Naghshe Jahan publication.

Todos los derechos reservados. Universidad de Costa Rica. Esta revista se encuentra licenciada con Creative Commons. Reconocimiento-NoComercial-SinObraDerivada 3.0 Costa Rica. Correo electrónico: humanidades@ucr.ac.cr/Sitioweb: http: //revistas.ucr.ac.cr/index.php/humanidades

CC BY-NC-ND 